\title{
Proposal To Change the Genus Designation Serpula to Serpulina gen. nov. Containing the Species Serpulina hyodysenteriae comb. nov. and Serpulina innocens comb. nov.
}

\author{
THAD B. STANTON \\ Physiopathology Research Unit, National Animal Disease Center, Agricultural Research Service, \\ U.S. Department of Agriculture, Ames, Iowa 50010
}

\begin{abstract}
The bacterial genus Serpula Stanton et al. 1991 is illegitimate due to the existence of a fungal genus Serpula Pers. ex S. F. Gray. Consequently, a new genus designation, Serpulina, is proposed for this spirochete genus. Serpula hyodysenteriae, the type species, and Serpula innocens Stanton et al. 1991, therefore, become Serpulina hyodysenteriae comb. nov. and Serpulina innocens comb. nov.
\end{abstract}

My colleagues and I have proposed a reclassification of the intestinal anaerobic spirochetes Treponema hyodysenteriae and Treponema innocens (21). This proposal was based on results of DNA-DNA reassociation experiments, sodium dodecyl sulfate-polyacrylamide gel electrophoresis of cell proteins, and 16S rRNA sequence analyses. Our results and the results of previous investigators $(16,17)$ indicated that $T$. hyodysenteriae and $T$. innocens are related to one another but are related only distantly to $T$. pallidum, type species of the genus Treponema, and to other spirochetes. Consequently, we proposed that the species $T$. hyodysenteriae and $T$. innocens be transferred to a new genus, Serpula gen. nov.

Recently, I learned that the name Serpula has been used to designate a genus of fungi belonging to the Class Basidiomycetes $(1,5,18)$. Species of this genus are associated with rotting wood and include $S$. lacrymans, which causes dry rot of lumber in buildings $(2,5)$. According to Rule $51 \mathrm{~b}$ of the International Code of Nomenclature of Bacteria (13), a bacterial name is illegitimate if it is a junior homonym (a name published later) of a taxon of bacteria, fungi, algae, protozoa, or viruses. Due to the prior use of the name Serpula for a fungal genus, the name Serpula for a bacterium is illegitimate and should be rejected.

Serpula translated from the Latin means "little snake." When viewed by phase-contrast microscopy, S. hyodysenteriae cells have a snakelike appearance (22). In recognition of this morphology, I propose that the bacterial genus name Serpula be replaced by Serpulina (ser.pu.li'.na) gen. nov. (L.n. serpula, little snake; L. suffix -ina belonging to; N.L. fem. n. Serpulina belonging to the class of little snakes, snakelike). Serpula hyodysenteriae and Serpula innocens would be transferred to the new genus as Serpulina hyodysenteriae comb. nov. and Serpulina innocens comb. nov. The type species would be $S$. hyodysenteriae, with strain B78 (= ATCC 27164) as the type strain. The genus description for these intestinal spirochetes is the same as the description for Serpula, and the species descriptions are the same as those for $S$. hyodysenteriae and $S$. innocens (21).

There is no indication that the name Serpulina has been used previously to designate taxa of bacteria $(4,7,10,20)$, protozoa $(11,14)$, algae $(8,12,19)$, fungi $(1,2,9,18)$, or viruses $(3,6,7,15,23)$. Computer searches of titles, key words, and abstracts of publication data bases (Agricola, 1970 to 1991; BIOSIS, 1969 to 1991; Zoological Record, 1978 to 1991; Commonwealth Agriculture Bureau Annotated Bibliography (CAB) Abstracts, 1972 to 1991; SciSearch, 1974 to 1991; Life Sciences Collection, 1978 to 1991; Medline, 1966 to 1991; Excerpta Medica Base, 1974 to 1991; and Chemical Abstracts Search, 1967 to 1991) have not revealed any prior use of the designation Serpulina.

I am grateful to Bruce Paster and Warren Thomas for bringing the existence of the fungal genus Serpula to my attention and to John G. Holt and Larry Wayne for opinions regarding the International Code of Bacterial Nomenclature. Janice Eifling conducted the computer searches of scientific literature. In selecting the designation Serpulina, the scholarly and sympathetic advice of Thomas $\mathrm{O}$. MacAdoo, Department of Foreign Languages and Literatures, Virginia Polytechnic Institute and State University, Blacksburg, Va., is greatly appreciated.

\section{REFERENCES}

1. Ainsworth, G. C., F. K. Sparrow, and A. S. Sussman (ed.). 1973. A taxonomic review with keys: basidiomycetes and lower fungi, vol. IVB. In The fungi. Academic Press, Inc., New York.

2. Alexopoulos, C. J., and C. W. Mims (ed.). 1979. Introductory mycology, 3rd ed. John Wiley and Sons, New York.

3. Benade, L. E., D. A. Stevens, N. Elliott, and J. Aebig (ed.). 1986. ATCC catalogue of animal and plant viruses, chlamydiae, rickettsiae, and virus antisera, 5th ed. American Type Culture Collection, Rockville, Md.

4. Buchanan, R. E., J. G. Holt, and E. F. Lessel, Jr. (ed.). 1966. Index bergeyana. The Williams \& Wilkins Co., Baltimore.

5. Cooke, W. B. 1957. The genera Serpula and Meruliporia. Mycologia 49:197-225.

6. Dalton, A. J., and F. Haguenau. 1973. Ultrastructure of animal viruses and bacteriophages: an atlas. Academic Press, Inc., New York.

7. Gherna, R., P. Pienta, and R. Cote (ed.). 1989. Catalogue of bacteria and bacteriophages, 17th ed. American Type Culture Collection, Rockville, Md.

8. Irvine, D. E. G., and D. M. John (ed.). 1984. Systematics of the green algae, vol. 27. Academic Press, Inc., New York.

9. Jong, S. C., and M. J. Gantt (ed.). 1987. Catalogue of fungi/ yeasts, 17 th ed. American Type Culture Collection, Rockville, Md.

10. Krieg, N. R., and J. G. Holt (ed.). 1984. Bergey's manual of systematic bacteriology, vol. 1. Williams \& Wilkins, Baltimore.

11. Kudo, R. R. 1966. Protozoology, 5th ed. Charles C Thomas, Publisher, Springfield, Ill.

12. Kützing, F. T. 1969. Species algarum. 1969. A. Asher and Co., Amsterdam. [Reprint of 1849 edition.]

13. Lapage, S. P., P. H. A. Sneath, E. F. Lessel, V. B. D. Skerman, H. P. R. Seeliger, and W. A. Clark (ed.). 1975. International code of nomenclature of bacteria. American Society for Microbiology, Washington, D.C.

14. Lee, J. J., S. H. Hutner, and E. C. Bovee (ed.). 1985. An 
illustrated guide to the protozoa. Society of Protozoologists, Lawrence, Kans.

15. Luria, S. E., J. E. Darnell, Jr., D. Baltimore, and A. Campbell. 1978. General virology, 3rd ed. John Wiley and Sons, New York.

16. Miao, R. M., A. H. Fieldsteel, and D. L. Harris. 1978, Genetics of Treponema: characterization of Treponema hyodysenteriae and its relationship to Treponema pallidum. Infect. Immun. 22:736-739.

17. Paster, B. J., E. Stackebrandt, R. B. Hespell, C. M. Hahn, and C. R. Woese. 1984. The phylogeny of the spirochetes. Syst. Appl. Microbiol. 5:337-351.

18. Singer, R. 1944. Notes on taxonomy and nomenclature of the polypores. Mycologia 36:65-69.

19. Smith, G. M. (ed.). 1951. Manual of phycology. Chronica
Botanica Company, Waltham, Mass.

20. Sneath, P. H. A., N. S. Mair, M. E. Sharpe, and J. G. Holt (ed.). 1986. Bergey's manual of systematic bacteriology, vol. 2 Williams \& Wilkins, Baltimore.

21. Stanton, T. B., N. S. Jensen, T. A. Casey, L. A. Tordoff, F. E. Dewhirst, and B. J. Paster. 1991. Reclassification of Treponema hyodysenteriae and Treponema innocens in a new genus, Serpula gen. nov., as Serpula hyodysenteriae comb. nov. and Serpula innocens comb. nov. Int. J. Syst. Bacteriol. 41:50-58.

22. Stanton, T. B., and D. F. Lebo. 1988. Treponema hyodysenteriae growth under various culture conditions. Vet. Microbiol. 18:177-190.

23. Wilner, B. I. 1969. A classification of the major groups of human and other animal viruses. Burgess Publishing Company, Minneapolis. 